\title{
What Is an Action? Peter Auriol vs. Thomas Aquinas on the Metaphysics of Causality
}

GLORIA FROST

University of St. Thomas, St. Paul, MN

This paper recovers a historically important debate about the ontological status of an agent's action. When one physical substance acts upon another what is the ontological status of the causal activity by which the former moves the latter? According to the Aristotelian position on action defended up through the seventeenth century, agents cause their effects immediately. There is no intervening causative entity by which an agent causes a change in its patient. The agent's action is the very motion or change which the agent causes. This paper examines Thomas Aquinas's intriguing development of the Aristotelian position and Peter Auriol's incisive critique. Auriol contends that a physical agent's action must be really distinct from, causally prior to, and separable from the motion which the agent causes. Auriol posits that actions are dynamic, fleeting causative entities which exist just as long as an agent is initiating a motion. The recovery of Auriol's position challenges a standard historical narrative which holds that up through the early modern period philosophers thought that causes must be persistent stable objects. Auriol's views show that transitory causative entities, such as forces and events, popularized in the mid-eighteenth century, have a legacy in medieval thought. Furthermore, Auriol's position that action is a really distinct and separable entity from motion anticipates an important shift in historical thinking about the nature of motion and its ability to persist without an active cause.

\section{Introduction}

It is commonplace in mainstream analytic philosophy to conceive of causation as a relation between events. On this picture, both causes and effects belong to the same ontological category-event-and in order to have an instance of causa-

Contact: Gloria Frost <gfrost@stthomas.edu> 
tion you need at least two of them. 'Dropping' causes 'breaking,' 'cutting' causes 'splitting,' and 'raising my arm' causes it 'to be raised. ${ }^{1}$ It is well-known that philosophers from the ancient through the early modern period conceived of the relata of causation quite differently. On their accounts causes are substances - not events. The ball which strikes causes the nine ball to sink, the child who drops causes the vase to break, and the person who raises her arm causes it to go up.

Little attention has been paid to another noteworthy difference between historical and contemporary accounts of causation: Following Aristotle, many medieval and early modern philosophers thought that correlative active and passive event descriptions refer to a single entity. Descriptions, such as 'cutting' and 'being cut,' 'burning' and 'being burnt,' 'teaching' and 'learning' pick out numerically the same motion. In the third book of his Physics Aristotle claims that one and the same motion is both what the agent does and what the patient undergoes. ${ }^{2}$ Although Descartes rejected much of the metaphysical machinery of his scholastic predecessors, he explicitly endorsed the 'action-passion sameness' thesis. He writes in his work on The Passions of the Soul, for instance:

I note that whatever takes place or occurs is generally called by philosophers a passion with regard to the subject to which it happens and an action with regard to that which makes it happen. Thus, although the agent and the patient are often quite different, the action and the passion must always be a single thing which hasthese two names on account of the two different subjects to which it may be related. (AT XI: $328, C S M K$ I: 328$)^{3}$

While the 'action-passion sameness' thesis was accepted by historical thinkers as diverse as Aristotle and Descartes, it is by no means entailed by the view that substances are causes. Many of the contemporary philosophers who have revived the notion of agent causation maintain that agent substances cause events in virtue of being part of distinct events which are their actions. An agent causes the event of the 'door's opening,' for example, by being part of the distinct event of 'opening the door.' The agent's action is not the same event as the door's 'being opened'-rather, it is a distinct causally prior event.4 Thus, even if it is accepted that substances are agents the question remains open of whether, in addition to substances and their effects, there is an entity which is the action or

1. For an overview of contemporary discussions of causation, see Paul and Hall (2013).

2. Aristotle, Physics, Bk. III, c. 3. For scholarship on this text in Aristotle, see for instance, Gill (1980) and Marmodoro (2007).

3. For an overview and analysis of the scholarly debate about how to interpret Descartes's position on action-passion sameness, see Schickel (2011).

4. For an overview of the debate about whether the actions of agents are events distinct from the event which the agent causes see Bach (1980), Alvarez and Hyman (1998), and Lowe (2002: esp. chs. 11-12). 
causal activity of an agent whereby it causes its effect. This paper retrieves a fascinating medieval debate about the ontological status of an agent cause's action.

The paper focuses on Thomas Aquinas's intriguing defense of the 'actionpassion sameness' thesis and Peter Auriol's incisive critique. On Aquinas's view, agents cause their effects immediately, that is, not in virtue of some intervening causative entity. On his view, the term 'action' refers to the very motion or change caused by the agent in so far as it is arising or originating from the agent. By contrast, on Auriol's view actions are entities over and above the motion which the agent causes. In his view, actions are fleeting, dynamic, essentially causative entities which exist just as long as an agent is causing its effect. Auriol's views are historically significant in so far as they show that the idea of dynamic causal entities had a precedent in medieval thought. This challenges a standard historical narrative which claims that from the ancient through early modern period natural philosophers thought that causes must be persistent substances or their stable properties. On this narrative, it was not until the eighteenth century that there was a shift toward positing transitory entities, such as forces, actions, and events, as causes. ${ }^{5}$ Furthermore, Auriol's position that causal activity is a really distinct and separable entity from motion anticipates an important shift in historical thinking about the nature of motion and its ability to persist without an active cause.

In addition to its historical significance, the medieval debate about 'actionpassion sameness' has enduring philosophical relevance. Aquinas's development of the 'action-passion sameness' thesis sheds light on how the position might be nuanced in an interesting way to withstand some obvious objections. Auriol's critique identifies the difficulties which must be overcome by its defenders. ${ }^{6}$

\section{Aquinas: An Agent's Action Is the Same as the Motion It Causes}

In order to grasp Aquinas's views on action and the broader disagreement between him and Auriol, it is necessary to first introduce some basic tenets of the Aristotelian approach to causation. In the Aristotelian framework, paradigm instances of natural causation involve an agent substance, a patient substance, and a motion or change which the agent causes in the patient. Furthermore, the agent is believed to act on the patient through an inherent active potency and the patient is thought to be acted upon in virtue of an inherent passive potency. For example, a case of a fire burning a log involves the fire and its active potential

5. See, for instance, Janiak (2016: §4).

6. For recent attempts in contemporary action theory to revive 'action-passion sameness' see Coope (2007) and Ford (2014). 
to burn, the log and its passive potential to be burned, and the motion of burning which the fire causes in the log. Auriol and Aquinas agree that instances of natural causation involve at least these five entities (i.e., an agent substance, a patient substance, an active power, a passive power, and a motion or change). The disagreement between the two figures concerned whether, in addition to these, there is a sixth entity that is the action whereby the agent causes the motion in its patient. For instance, does fire cause burning in the log in virtue of a distinct entity which is its action of burning?

Aquinas's most extensive discussion of the ontological status of an agent's action occurs in his commentary on Book III of Aristotle's Physics.7 In this book, Aquinas follows Aristotle by first discussing the definition of motion and then the question of which substance is the subject whose potency is actualized by motion (i.e., the agent's or the patient's). In the Aristotelian framework, 'poten$\mathrm{cy}^{\prime}$ and 'act' are correlative notions which express a certain type of relationship between two realities. A potentiality is a reality which is in some respect incomplete, imperfect, or unrealized. For every potentiality, there is a corresponding actuality which relates to it as its realization and fulfillment. ${ }^{8}$ For example, actually seeing is the actuality which corresponds to a sleeping person's potential to see; and the act of building is the actuality which corresponds to a resting builder's potential to build. The term 'action' refers to the act of an active potency and term 'passion' refers to the act of a passive potency. 9 In his commentary on Physics III, Aquinas asks whether the motion which a patient undergoes is the manifestation or completion of the agent's active potential to cause motion (i.e., the agent's action) or the patient's passive potential to undergo motion (i.e., the patient's passion). For example, is the burning which happens in the log the fulfillment and completion of the $\log ^{\prime}$ s potential to be burned or the fire's potential to burn another?

Aquinas thinks that the definition of motion makes clear that the motion which the patient undergoes must be the act of the patient's potential to undergo change. ${ }^{10}$ Following Aristotle, Aquinas conceives of motion as an imperfect actuality which (i) relates as potency to a further act and (ii) relates as act to a prior potency. Aquinas uses the motion of heating as an example to illustrate this definition. The imperfect heat a subject has while being heated is the realization or fulfillment of the subject's prior potential for heat and yet, that heat is at the same time imperfect or unrealized in comparison with the greater heat the

7. Aquinas also discusses this issue in In XI Meta., 1. 9. This discussion is shorter and the main arguments overlap substantially with the Physics commentary discussion.

8. See for instance In IX Meta., 1. 5.

9. Aquinas explains in In III Phys., 1. 5, n. 2.

10. For the definition of motion see In III Phys., 1. 3, n. 2 (1884: 108): "[M]otus igitur est actus existentis in potentia inquantum huiusmodi." 
subject is acquiring. ${ }^{11}$ In Aquinas's view, the motion of heating is in itself that very heat which is both act with respect to a prior state and potency with respect to a greater posterior heat. Aquinas reasons that the imperfect act which is motion must be the realization or fulfillment of the patient's potential to be moved since during a causal interaction the patient is the very substance which is in act while also retaining potential for a greater actuality. For example, during an instance of heating the water which is being heated retains the potential to be more perfectly hot even while it is actually hot. The agent, by contrast, does not necessarily retain a potential for a greater actuality even while it acts. Fire, for example, does not necessarily retain the potential to heat more perfectly even while it is heating in actuality. ${ }^{12}$ Since motion is a type of actuality which is the act of a subject remaining in potency, it must necessarily be the act of the patient undergoing change. Given that motion is the act of the patient, does this imply that there must be some additional actuality which is the actualization of the agent's active potential to cause motion? We now turn to Aquinas's reply to this question.

Aquinas argues that the actualization of the agent's active potential must be the same act that actualizes the patient's passive potential. He writes:

This is why it is necessary that there is one act of both the mover and the moved: that which is from the mover as agent cause and that which is in the moved as patient and recipient is one and the same reality. ${ }^{13}$

Aquinas reasons that since what the agent causes is the same reality that the patient undergoes, it must be the case that the actualization of the agent's potential to move is also the actualization of the potential's potential to be moved. The manifestation and fulfillment of the mover's active potency is the very motion which the moved substance undergoes.

To further support this view, Aquinas argues that absurdities follow if it is posited that the action whereby an agent causes motion is a distinct entity from the motion which the patient undergoes. Aquinas assumes that action (i.e., the act of an active potency) and passion (i.e., the act of a passive potency) must be in themselves motions. ${ }^{14} \mathrm{So}$, if it is assumed that an agent's action is not the same as the motion in the patient, then there will be two motions involved in instances of

11. In III Phys., 1. 2, n. 3.

12. In III Phys., 1. 4, n. 1. For the details of Aquinas's argument that motion must be the actuality which corresponds to the patient's potential to be moved, see Frost (2018: 52-53).

13. In III Phys., 1. 4, n. 10 (1884: 110): “Quare oportet unum actum esse utriusque, scilicet moventis et moti: idem enim est quod est a movente ut a causa agente, et quod est in moto ut in patiente et recipiente." All English translations are my own.

14. In III Phys. 1. 5, n. 3. For Aristotle's claim that actions are motions see his Phys. Bk. III, c.2, 11. $202 \mathrm{a} 25$. 
causation. The second motion which is the agent's action must occur in a subject (i.e., in the agent or the patient). The first possibility is that action is a motion which happens in the agent to enable it to cause the subsequent motion which is the passion of the patient. On this model, the action of heating would be some change which happens in fire which enables it to burn the log. The second possibility is that action is a motion which happens in the patient which is prior to and causative of the motion which is properly the patient's passion. On this model, the act of burning would be some initial causal impacting which fire makes on the log which in turn gives rise to the burning. Aquinas thinks that both of these possibilities lead to absurdities.

Regarding the supposition that action is a motion in the agent, he writes: "[I]t follows then that either every mover is being moved or something has motion and it is not being moved. Both of these possibilities are unreasonable."15 Aquinas had already explained earlier in his commentary on the Physics why it is unreasonable to think that movers are themselves moved in so far as they act. ${ }^{16}$ In Aquinas's view, motion is the process whereby a substance gains a perfection. Through heating, for example, the log acquires the perfection of being hot. Moreover, he thought that through action agents pass on or share their perfection with the substance upon which they act. ${ }^{17}$ When fire heats, it makes the log hot like itself. The fire must itself be hot to heat another. Since action presupposes that a substance is already perfect, while motion is the process of acquiring a perfection, Aquinas reasoned that it would not make sense to think of an agent's action as a motion which it undergoes itself when it acts. For instance, it is irrational to think that fire's act of heating is a heating which occurs in fire itself because the fire must itself already be hot in order to engage in the activity of heating.

Aquinas then considers the possibility that the agent's action is a distinct motion that occurs in the patient prior to the motion which is the patient's passion. He reasons that this possibility also leads to incoherency. Both motions in the patient would have to be of the same species or kind since both aim at the same end state. For instance, both the initial motion and the subsequent motion which are caused by the fire in the log would be 'heatings' since both changes are ordered toward making the log hot. But if the motions are both of the same kind and both are in the same substance, then there would be no basis for distinguishing them as two motions. Suppose, for example, that a flame triggers an initial

15. In III Phys., 1. 5, n. 4 (1884: 112): “Si enim aliquis dicat quod actio est in agente et passio in patiente; actio autem est motus quidam, ut dictum est; sequitur quod motus sit in movente ... sequitur vel quod omne movens moveatur, vel quod aliquid habeat motum et non moveatur; quorum utrumque videtur inconveniens."

16. In III Phys. 1. 4, n. 6 (1884: 110).

17. See for instance ST I.19.2 co. 
motion in the water which has the motion which is the passion of heating as its causal consequence. We can ask, what is the outcome or goal which this initial change would be leading up to? The answer would have to be the final state of the water's being more perfectly hot. But this is the same goal that the subsequent change leads up to. Thus, there would be no basis to distinguish these two motions as two motions. One would simply be an earlier stage and the other a later stage of the same motion. ${ }^{18}$

After Aquinas argues that one and the same motion must be both the agent's action and the patient's passion, he goes on to consider a number of difficulties for this view. Many of the objections center upon the worry that both the difference in meaning and reality between causing and being caused will collapse if the actualization of the agent's and the patient's respective potentialities consist of a single motion. For instance, it seems that what is to heat and what it is to be heated will be one and the same if both the action of the fire and the passion of the log are the same motion. In the responses to the objections, Aquinas further clarifies the relationship between action, passion and motion.

Aquinas emphasizes that though a single motion actualizes both the agent's and the patient's respective potentialities, it actualizes each in a different way. He writes:

The very same act according to reality corresponds to two according to diverse accounts [rationem]: It is of the agent in so far as it is from it, and it is of the patient in so far as it is in it. ${ }^{19}$

Elsewhere Aquinas explains that there are two different ways in which an actuality can perfect or realize a potentiality. ${ }^{20}$ Some actualities, such as forms, perfect or complete potential by means of inherence. The form of whiteness, for instance, perfects a substance's potential to be white by inhering in the substance. Other acts, however, fulfill or realize their corresponding potentialities not by inhering, but rather by arising from them. In the case of natural causation,

18. In III Phys., 1. 4, n. 5.

19. In III Phys., 1. 5, n. 10 (1884: 113): “Sic enim idem actus secundum rem est duorum secundum diversam rationem: agentis quidem secundum quod est ab eo, patientis autem secundum quod est in ipso."

20. In IX Meta., 1. 5 (1964: 437): “. . diversimode dicatur actus . . non omnia dicimus similiter esse actu, sed hoc diversimode. Et haec diversitas considerari potest per diversas proportiones. Potest enim sic accipi proportio, ut dicamus, quod sicut hoc est in hoc, ita hoc in hoc. Utputa visus sicut est in oculo, ita auditus in aure. Et per hunc modum proportionis accipitur comparatio substantiae, idest formae, ad materiam; nam forma in materia dicitur esse. Alius modus proportionis est, ut dicamus quod sicut habet se hoc ad hoc, ita hoc ad hoc; puta sicut se habet visus ad videndum, ita auditus ad audiendum. Et per hunc modum proportionis accipitur comparatio motus ad potentiam motivam, vel cuiuscumque operationis ad potentiam operativam." 
the same motion completes or perfects the agent's and the patient's respective potencies in two distinct ways. The motion completes the patient's potential by existing in the patient as that in virtue of which the patient is moving. By contrast, the motion realizes the agent's potential by arising or originating from it.

This difference in how the motion relates to the agent and the patient provides a basis for distinguishing action and passion from each other in reality. Aquinas writes:

Although action and passion are the same motion it does not follow that action and passion are the same because action implies an order toward that from which there is motion in the mobile, and passion implies something which is from another. ${ }^{21}$

In Aquinas's view motion considered merely in itself, that is, abstracting from the dependence it has on the agent and the patient, is an imperfect actuality (e.g., an imperfect quality or quantity). To describe a motion as an action or a passion is to refer to it together with one of these distinct ways in which it depends on a substance. An action is a motion originating from a substance; a passion is a motion received in a substance from another.

Aquinas is committed to the view that each of the ten Aristotelian categories pick out distinct realities which exist outside of the mind. ${ }^{22}$ Since action and passion are among the Aristotelian categories, he explicitly considered the worry that the view that action and passion are the same motion would collapse the difference between the realities which the categories of action and passion are supposed to distinguish. ${ }^{23}$ Aquinas claims that in order to understand how the 'same motion' view avoids this problematic implication, it is important to understand the sort of division of reality which the ten categories mark out. According to Aquinas, the ten categories divide modes of being (modus essendi). ${ }^{24}$ This is to say that they divide differences in how an entity exists, as opposed to differences

21. ST I.28.3 (1886-1906: 324): “. . . licet actio sit idem motui, similiter et passio, non tamen sequitur quod actio et passio sint idem, quia in actione importatur respectus ut a quo est motus in mobili, in passione vero ut qui est ab alio."

22. See, for instance, De pot. 7.9 (1965: 208): "In nullo enim praedicamento ponitur aliquid nisi res extra animam existens. Nam ens rationis dividitur contra ens divisum per decem praedicamenta ut patet V Metaph."

23. For recent discussions of Aquinas's views on the relationship between action, passion and motion, see Frost (2018), Brower (2014: 205-210), and Pasnau (2011: 230-232).

24. De ver. 1.1 (1970-1976: 5): “Sunt enim diversi gradus entitatis, secundum quos accipiuntur diversi modi essendi, et iuxta hos modos accipiuntur diversa rerum genera: substantia enim non addit super ens aliquam differentiam quae designet aliquam naturam superadditam enti sed nomine substantiae exprimitur specialis quidam modus essendi, scilicet per se ens, et ita est in aliis generibus." 
which arise through the addition of a nature. ${ }^{25}$ Such differences can best be illustrated with an example. The difference between a particular substance, such as Socrates, and a particular accident, such as Socrates's whiteness, is not merely a difference in nature or essence, as is the difference between a cat and a dog or between brownness and greenness. More fundamentally, a substance and an accident differ with respect to how they exist. One exists of itself, while the other exists as something belonging to another being. ${ }^{26}$ According to Aquinas, each of the genera marked out by Aristotelian categories similarly tracks a division in reality between modes of being. While all accidents depend upon substance for their existence, accidents can be distinguished according to different genera in virtue of the differences in how they depend upon or are of a substance. Quality, for example, is a different category of accident than quantity because belonging to a substance as a qualitative modification of it is a different way of being of a substance than belonging to a substance as a measure of it.

As already mentioned, Aquinas thinks the point about how different categories of accident are distinguished from each other, that is, in terms of modes of being-or as I have glossed it, different ways of being of or belonging to substance - is crucial for understanding how action and passion can both be the same motion (i.e., the same actuality), and yet, different accidents from each other. ${ }^{27}$ He writes in his commentary on the Metaphysics:

Similarly, motion in so far as it is predicated of the subject in which it is constitutes the category of passion. However, in so far as it is predicated of the one from which it is, it constitutes the category of action. ${ }^{28}$

25. On Aquinas's understanding of 'modes of being' see Tomarchio (1998; 1999; 2001).

26. In VII Meta., 1. I (1964: 317): “. . . modus essendi accidentium non sit ut per se sint, sed solum ut insint ..." In VII Meta. 1. I (1964: 316): "Sed substantia est ens simpliciter et per seipsam: omnia autem alia genera a substantia sunt entia secundum quid et per substantiam: ergo substantia est prima inter alia entia."

27. After introducing the worry that the distinction between action and passion as categories will collapse if action and passion are the same motion, he writes in his Physics commentary: In III Phys., 1. 5, n. 15 (1884: 114): "[S]ciendum est quod ens dividitur in decem praedicamenta non univoce, sicut genus in species, sed secundum diversum modum essendi. Modi autem essendi proportionales sunt modis praedicandi. Praedicando enim aliquid de aliquo altero, dicimus hoc esse illud: unde et decem genera entis dicuntur decem praedicamenta." See also In V Meta. 1. 9, n. 890 (1964: 238).

28. In VII Meta., 1. I (1964: 317): "Similiter motus, secundum quod praedicatur de subiecto in quo est, constituit praedicamentum passionis. Secundum autem quod praedicatur de eo a quo est, constituit praedicamentum actionis." See also In III Phys., 1. 16, n. 2 (1884: 115): "Sic igitur patet quod licet motus sit unus, tamen praedicamenta quae sumuntur secundum motum, sunt duo, secundum quod a diversis rebus exterioribus fiunt praedicamentales denominationes. Nam alia res est agens, a qua sicut ab exteriori, sumitur per modum denominationis praedicamentum passionis: et alia res est patiens a qua denominatur agens. Et sic patet solutio primae dubitationis." 
Aquinas is committed to the theses that (1) the categories of accident mark out distinct ways in which an actuality is of or belongs to a substance and (2) motion is of or belongs to two substances according to two different ways. It follows from these commitments that (3) motion is the same as two different types of accident. ${ }^{29}$ For Aquinas, a categorical accident is not merely an actuality considered in itself. It is an actuality taken together with a particular way of belonging to, being of, or depending on a substance. If one and the same actuality is of two different substances, then it will constitute two different accidents.

Aquinas's position can be better illustrated through an example: The motion of heating, for instance, is just the imperfect heat which has begun to be in the water which the fire is acting upon..$^{30}$ This imperfect heat is not of itself an action or a passion. Action refers to the heat together with its dependence on the fire's active power. In addition to arising from the heat's active power, the same heat is inhering in the water as received from another (i.e., the heat only exists in the water on account of the fire's active causality). To refer to the heat as the water's passion is to refer to the heat together with this particular manner in which it belongs to the water. As Aquinas writes, "Although motion is the common act of the mover and the moved, nevertheless it is one operation to cause motion and another to receive motion, and thus, there are two categories posited 'to do' and 'to suffer."' 31 Though heating and being heated involve the same physical process, the action of heating is not the same as the passion of being heated. To perform the action of heating is to have that process arising from one's active power; to be heated is have the process inhering in oneself through the agency of another.

The mind-independent difference between the relationship which the agent has to the motion and the relationship which the patient has to it is underscored by Aquinas's repeated claim that "passion is an effect of action." 32 Initially, it

29. 'Sameness' here should not be taken as 'identity' in the modern sense. According to the modern sense of 'identity,' two entities are identical if they share all of the same properties. In Aquinas's view, motion considered in itself does not share all of the same properties as action and passion. In addition to the properties of the motion, action and passion each include a different dependence on a particular substance. 'Motion' considered in itself does not include these dependencies on an agent and patient among its properties.

30. In III Phys., 1. 5, n. 17 (1884: 115): "De motu enim in rerum natura nihil aliud est quam actus imperfectus, qui est inchoatio quaedam actus perfecti in eo quod movetur: sicut in eo quod dealbatur, iam incipit esse aliquid albedinis." Not every imperfect actuality is a motion, however. Aquinas goes on in this passage to explain that an imperfect act only satisfies the definition of motion in so far as certain states precede and follow it.

31. ScG II.57, n. 1334 (1961: 183): “Licet motus sit communis actus moventis et moti, tamen alia operatio est facere motum et recipere motum: unde et duo praedicamenta ponuntur facere et pati."

32. ST I.44.2 ad I (1886-1906: 458): “. . p passio est effectus actionis.” De ver. 26.2 (1970-1976: 752): “. . . passio patientis derivatur ab agente, eo quod passio est effectus actionis." See also ST I.97.2; In V Ethic., 1. 14, n. 7. 
seems incoherent to hold that action is the cause of passion, while also maintaining that action and passion are the same motion, since this seems to imply that one and the same motion causes itself. But what must be kept in mind is that 'action' and 'passion' do not signify the motion by itself. As we have seen, these terms refer to the motion together with a real, mind-independent way in which it belongs to a substance. When Aquinas claims that passion is an effect of action, what he means is that the motion's being of the patient as something received by it ontologically depends on the motion's being of the agent as something causally arising from it. If the motion were not arising from the agent, it would not be received in the patient. An action can never be temporally prior to its correlative passion because what time measures is motion and action and passion both involve the same motion. Yet, causing and receiving are really different ways in which a substance can be related to a single motion and one of these relationships is causally prior to the other. 33 Though they happen simultaneously, the patient's receiving causally depends on the agent's causing.

From this section we can conclude that for Aquinas, though action is not an entity over and above the motion which the agent causes, the agent's action is neither strictly identical to nor reducible to the motion it causes. In Aquinas's view, an action is a motion that has a particular sort of ontological dependence on an agent. Actions are motions which are arising or originating from an agent. In Aquinas's view, cases of natural causation involve only these five entities: an agent and its active power, a patient and its passive power, and a motion. However, also crucial to understanding the metaphysics of causation are two mindindependent types of dependencies which a motion can have on a substance. In Aquinas's view, causation cannot be fully understood merely in terms of the entities it involves because the essence of causation involves a special manner in which one entity depends on another for its origin.

\section{Peter Auriol: Action Is an Entity Over and Above Motion}

Peter Auriol discusses the ontological status of action in a number of different texts. ${ }^{34}$ Here I focus on the one text in which he explicitly critiques Aquinas's

33. ST I.45.2 ad 2 (1886-1906: 466): "Sed cum actio et passio convenient in substantia motus, et differant solum secundum habitudines diversas ... oportet quod subtracto motu, non remaneat nisi diversae habitudines."

34. Auriol discusses the categories of action and passion in several different texts. Auriol's refutation of Aquinas's position that action and passion are in reality the same as motion is contained in Scriptum in I Sent. 27.1.1-4, which is on the distinctions between the divine persons. This text is dated to 1316 and it is edited in the appendix to Friedman (1997). Friedman has revised some of the punctuation in the text and an updated version of the edition (Auriol 2009). My own citations are to this latter edition. Other important texts for Auriol's views on action include: In II 
position that an agent's action is the motion which it causes. The goal of Auriol's arguments is to establish that action must be an entity distinct from and really separable from motion. ${ }^{35}$ Auriol maintains that in addition to substances and their attributes a viable ontology must include further transitory causative entities to capture the dynamic nature of an agent's initiating of motion in its patient.

Auriol's arguments against Aquinas can be grouped into two categories: His first two arguments are based on examples of causation from the physical world which supposedly show that motion is neither necessary nor sufficient for causal activity to occur. Thus, motion cannot be the actualization of the agent's active potential. His second set of arguments are metaphysical in character. They aim to show that the objective reality of efficient causation cannot be maintained unless there is some entity which is the agent's causal activity over and above the agent and the motion which it causes. There is some evidence that Auriol may have been influenced by earlier scholastic debates as he developed his arguments against Aquinas's position. Peter Olivi explicitly considered the question of whether a mover causes motion in its patient immediately or by a really distinct influx or impression of causality which is prior to the motion in the patient. ${ }^{36}$ There is some overlap between the arguments which Olivi adduces for the latter position and Auriol's arguments against Aquinas. In what follows I will reconstruct each of Auriol's arguments.

Auriol's first two arguments aim to show that motion cannot be the agent's action because causal activity and motion can exist apart from each other. First, he provides examples of causal activity which occur without motion. One example is illumination. Medieval thinkers held that the sun caused light in air instantaneously, rather than by gradually and successively changing the air through motion. Thus, the sun's action of illuminating the air cannot be a motion in the

Sent. 1.3 [“Utrum creation sit de genere relationis, an de genere passionis"] in (1605a: 21-23); In IV Sent. 13.1.2 [Utrum transubstantio sit actio de genere actionis] in (1605b: 125-128); and Quodlibet 2 [Utrum action agentis differat realiter ab agente] which is edited in Nielsen (2011).

35. Scriptum in I Sent. 27.1.1 (2009: 9, 11. 354-353): "Quod actio et passio sunt praedictamenta realia, et inter se realiter distincta, contra id quod opinatur Thomas, parte prima. Secunda vero propositio est quod actio et passio, secundum suas rationes formales sunt vere res extra intellectum existentes, differentes quidem realiter inter se et ab agente et passo." As we have seen, Aquinas does in fact maintain that action and passion are really distinct modes of being. On Aquinas's view, differences of mode are a sufficient basis for positing distinct categories. Auriol, however, supposes that the categories, such as action and passion, divide distinct entities, rather than distinct modes.

36. See Olivi's Q. XXIX [“An motus fiat immediate a motore”] (1922: I 499-504). See especially pp. 500-501 where it is argued that the agent's impression of causality must be really distinct from the motion because these can exist separately in projectile motion and in the production of light. 
air because there is no motion in this case. 37 This counterexample is supposed to show that action must be a reality other than motion. ${ }^{38}$

Next Auriol goes on to argue that motion cannot be equated with the manifestation of an agent's active power because there are motions which are not being actively produced by an agent. He identifies projectile motion as an evident example of this. He writes:

Motion is distinct in reality from action and passion. This is because motion remains with the action passing away as is apparent with projectiles: The motion of projectiles remains even with the act of the projector ceasing and indeed it would remain even if the projector were annihilated. 39

As Auriol sees it, the case of motions which persist apart from the actions which initiate them proves that motion and action are distinct entities. If motion and action were truly identical, they would likewise be inseparable.

It is worth noting that many scholastic figures, including Aquinas, would have rejected Auriol's assumption that the action of the projector ceased once the projectile is launched and no longer in physical contact with the projector. The majority of medieval Aristotelians thought that projectile motion could not exist without continuously arising from a conjoined cause. On the standard view, the thrower was conceived of as imparting a force [vis impulsus] to the projectile (or the air surrounding it) which continued to move it after it lost contact with the projector. Because the projector was the one who imparted the force from which the motion continued to arise, the motion was conceived of as constituting the projector's action. The imparted force was conceived as an instrument of the projector. ${ }^{40}$ Auriol finds this aspect of the standard view especially problematic

37. Scriptum in I Sent. 27.1.1 (2009: 9-10, 11. 384-386).

38. Like Auriol, Aquinas acknowledged that there were natural causes which produced their effects instantaneously, i.e., without motion. He claims that in an instantaneous action that action is the very effect. See his De aeternitate mundi. It seems that in Physics III, he is only addressing cases of natural causation which involve motion and he concludes that in these cases the motion is the agent's action in so far as it arises from the agent's power. It is consistent with this view to maintain that when effects are produced instantaneously without motion, something else, namely the effect itself, constitutes the agent's action.

39. Scriptum in I Sent. 27.1.1 (2009: 10, 11. 389-391): "[M]otus distinguitur realiter ab actione et passione, et quia manet motus, transeunte actione, sicut apparet in projectis, manet enim motus projectorum projiciente cessante, immo eo annihilate maneret."

40. For Aquinas's endorsement of this view, see De pot. 3.11 ad 5 (1965: 75): “. . . instrumentum intelligitur moveri a principali agente, quamdiu retinet virtutem a principali agente impressam; unde sagitta tamdiu movetur a proiciente, quamdiu manet vis impulsus proicientis. Sicut etiam generatum tamdiu movetur a generante in gravibus et levibus quamdiu retinet formam sibi traditam a generante; unde et semen tamdiu intelligitur moveri ab anima generantis quamdiu remanet ibi virtus impressa ab anima, licet corporaliter sit divisum. Oportet autem movens et 
because it implies that agents which no longer exist can continue to act in the world. ${ }^{41}$

Auriol's metaphysical arguments, which have to do with the nature of causality and causal connections, become standard arguments in late-scholastic discussions of agency and causality..$^{42}$ I will refer to his first argument as the 'causal priority' argument. This argument is fairly straightforward and can be reconstructed as follows:

1. Nothing can be the same as what it causally depends on (according to efficient causation). 43

2. The motion in the patient causally depends on the agent's action (according to efficient causation). ${ }^{44}$

3. Therefore, the motion in the patient cannot be the same as the agent's action.

The first premise of this argument is non-controversial. It is clear that nothing can be the efficient cause of itself because a thing would have to exist prior to

motum esse simul quantum ad motus principium, non tamen quantum ad totum motum, ut apparet in proiectis." There are other texts in which Aquinas seems to endorse Aristotle's account of projectile motion according to which the projector impresses a force onto the air rather than onto the projectile. See In VIII Phys. 1. 22 and In III de Caelo et Mundo 1. 7.

41. Projectile motion continued to be an important test case for thinking about the ontological relationship between action and motion up through the early modern period. Descartes argued, like Auriol, that the motion of a spinning top could not continue to be the action of the whip which initially set in motion or else causes which ceased to be could continue to act in the world. See "Letter to Hyperaspistes, August 1641," (AT III: 428). Yet, rather than claiming (as Auriol did) that such motion was not an action, he maintained that the top's persistence in motion was an action of the top upon itself once it ceased be conjoined with the agent which set it in motion. See AT VII: 367, CSMK II: 253. By contrast, Pierre Gassendi accepted, like Aquinas, that the projectile's continued motion continued to be the action of the projector even after it leaves the projector's hand. He explicitly claims that the motion would remain his action even if he were annihilated before the motion ceased. See his 'Letter to Diodati' (1972: 143).

42. For instance, arguments similar to these are repeated by Suárez in Disputationes Metaphysicae 48.1.15 and 18.10.8. For a recent treatment of Suárez's theory of action see Tuttle (2016).

43. Scriptum in I Sent. 27.1.1 (2009: 9, 11. 366-371): "[I]mpossible est rem aliquam in ordine causalitatis effectivae dependere a se ipsa ... [I]mpossible tamen est in ordine causalitatis activae quod idem sit sui ipsius causa. Nulla enim res est quae se ipsam gignat ..." The "according to efficient causation" is added on here because medieval thinkers recognized, following Aristotle, other types of causation (e.g., final causation, material causation). Auriol maintains that with regard to formal causation a reality can depend on itself. For Auriol's views on this, see Pasnau (2011: 216-220).

44. Scriptum in I Sent. 27.1.1, (2009: 9, 11. 373-375): "Sed manifestum est quod productum in ordine causalitatis effectivae dependet ab origine sive a respectu originis, unde dependet in esse suo ab actione et passione." He explicitly applies this argument to action and motion several lines down where he writes (2009: 10, 1. 391): "[Q]uia motus dependet ab actione motoris in ordine causalitatis effectivae..." 
itself in order to bring itself into existence. The second premise states that in a case of efficient causation, the motion which a patient undergoes depends on the agent's action as an efficient cause. This is to say that the agent's action originates or initiates the motion in the patient. This premise seems to fit with ordinary intuitions. For instance, it seems plausible that the fire's action is what causes the burning in the log. Auriol concludes on the basis of these two premises that the agent's action must, therefore, be really distinct from the motion which the patient undergoes. For instance, if fire's action causes or initiates the burning in the log, then fire's action must be really distinct from the burning. It must be causally prior to it. There is no way that action can be both the cause of motion and the same as it.

Later scholastics explicitly considered the issue raised in Auriol's argument in the context of responding to the question of "Whether action is the causality of the efficient cause." Following Auriol, they realized that it is incompatible to maintain that action is both a cause of motion and the same as it. Yet, rather than joining Auriol in concluding that action must be an entity over and above motion, some denied the premise that 'action is an efficient cause of motion.' 45 But, if agents do not cause motion in virtue of performing an action, how is it that agents cause motion? Some later figures identified the causality of an agent with its active causal powers (i.e., active inherent forms). Active powers are properties of agent's in virtue of which they are perpetually poised to initiate changes or motions. On this view, the agent need not do anything to initiate motion in its patient. Because they possess inherently causal properties, a substance can initiate motion immediately upon contact with its patient without relying on any intervening causal entity.

We can now move on to Auriol's next metaphysical argument for the real distinction between action and motion. The 'Causal Connection' thought experiments aim to show that without positing that an agent's action is an entity over and above motion, there is no way to distinguish between genuine cases of efficient causation and mere conjunctions of agents and motions. Auriol thinks that if, as Aquinas supposes, all that exists during a causal interaction is an agent and a motion in a patient, there will be nothing in reality which grounds the causal connection between the agent and the motion in the patient.

The first thought experiment involves two potential movers which are physically proximate to the same patient. Auriol stipulates that one of the movers is the actual cause of the motion in the patient, while the other is causally inactive.

45. See for instance Paul Soncinas, Quaestiones Metaphysicae, V.4 [“Utrum causalitas causa agentis sit agere"], (1498: 51): “. . causalitas est quid sit principium formale quo agens agit . . Actio non est formale principium, quo agens agit. Nullus effectus est formale principium, quod causa agit: quia quodlibet huius principium est prius effectu. Sed actio agentis est effectus eius: ergo non est formale principium quo agit." 
If we suppose following Aquinas that the only really separable entities in this scenario are the two possible movers, the patient and the motion, then there is nothing in extra-mental reality which allows us to ontologically differentiate between the true mover and the causally inactive one. To put his point differently: Suppose that patient $P$ is undergoing motion $m$ and suppose that substance $A$ is the agent which causes $P^{\prime}$ s motion and substance $B$ is a causally inactive substance proximate to $P$. If all that exists is $A$ and $B, P$ and $m$, then there is no adequate truth-maker for the truth of the statements: ' $A$ is the agent cause of motion $m^{\prime}$ and ' $B$ is not the agent cause of motion $m .{ }^{\prime}{ }^{46}$ Auriol concludes that there must be some additional entity which is the causal connection between the motion and the mover which originated it. 47

The second thought experiment involves the case of a particular instance of fire burning a log. Like his medieval interlocutors Auriol thought it was possible for God to produce any effect of a created cause solely through his own power without the cooperation of the creature..$^{8}$ In the thought experiment, after fire has been burning the log, God suspends the activity of the fire and takes over production of the burning in the log himself. In this situation, the fire and the motion of burning in the log remain, but yet there is no action from the fire. 49 Auriol reasons that it must be held that actions are really distinct entities from motion in order to find a way of ontologically distinguishing between the case of a mere conjunction of fire and burning and the case in which fire actually is the productive agent which causes burning. Like in the previous case he thinks there must be some entity which ties or links an agent to its effect.

It is clear from Auriol's critique of Aquinas's position that he was committed to the thesis that actions are entities really distinct from and separable from mo-

46. Scriptum in I Sent. 27.1.1 (2009: 10, 11. 392-400): "Praeterea, si actio et passio non differrent a motu et non essent res verae secundum suas rationes formales, posito motu in aliquo mobili, non posset ratio assignari quare plus esset $a b$ uno motore quam ab alio, positis duobus motoribus et appropinquatis ad mobile. Constat enim quod motus talis mobilis potest profluere ab alterutro duorum moventium, et intellectus aeque potest fundare super motum respectum ad unum, sicut ad aliud, quantum est ex natura moventium, et ex natura ipsius motus. Nisi igitur ponatur quod motus habet aliquam connexionem plus cum uno motore quam cum alio extra omnem intellectum (utpote quia oritur $\mathrm{ab}$ uno et non ab alio, et quia unum agit motum, reliquum non agit), non poterit intellectus connectere motum cum suo proprio et determinate motore."

47. Scriptum in I Sent. 27.1.1 (2009: 10, 11. 400-403): "Sed hoc est omnino absonum et impossibile. Ergo necesse est quod in rerum natura ultra motum et motorem sit realis connexio motus ad ipsum motorem sub respectu originis motus a motore et actione motoris."

48. There was disagreement about whether God acting alone could produce numerically the same effect as would have been produced by a particular creature or whether God could merely produce effects the same in species as those which creatures are able to produce. On this debate, see Keele (2007). Auriol's argument presupposes that God can produce numerically the same effects as creatures.

49. Scriptum in I Sent. 27.1.1 (2009: 10, 11. 407-415). 
tion. ${ }^{\circ}$ According to Auriol, actions (and passions) are fundamentally different types of beings from substances and their qualities and quantities. While these latter beings are persistent and static, actions are transitory and dynamic. Auriol claims that although we can think of and speak of actions using noun terms, verbs more aptly track their ontological status..$^{11}$ He writes:

The difference which divides action and passion from other beings ... is that they are not beings which are made, but the very makings (factiones) by which other beings are made. Accordingly, they are a way (via) or going forth (exitus) into existence ... ${ }^{2}$

In Auriol's view, actions do not function to characterize a single substance (i.e., they are not monadic properties) as is the case with qualities and quantities. Rather, actions by their nature exist between two entities, namely an agent and its effect. Auriol writes:

action is nothing other than a medium (intervallum) or a path (via) from agent into the patient or a reaching (attingentia) according to which is said that the agent reaches (attingere) the effect, and reaches forth and flows into it (egredi ac fluere in ipsum). 53

Similarly he writes, "the formal ratio of action is nothing other than a certain reaching of one thing into another, it is a reaching (attingentia) by which the agent is formally said to reach (attingere) and to cause the effect." 54 An action is the very causality of the agent by which it produces its effect in being. In Auriol's words, an action is a "causal medium" (medium ... causale) "binding" (ligans)

50. For literature on Auriol's understanding of action see the introduction in Nielsen (2011), Amerini (2014), and Löwe (2017).

51. Scriptum in I Sent. 27.1.3 (2009: 26, 11. 1061-1068): “. . . et talia quidem realiter pertinent ad agere vel pati, prout per verba proprie exprimuntur, habent tamen ex opera intellectus, prout per nomina exprimuntur et quiete concipiuntur, quod spectent ad aliud genus. Nulla autem res in natura existit, cuius esse sit in egressu formaliter, nisi illud intervallum, de quo supra dictum est quod intelligitur inter producens et productum, quod est attingere causitvum quo producens, quo formaliter dicitur productum produci; nulla vero alia res dicitur egredi vel esse in fieri, nisi ratione istius intervalli."

52. Quodl. q. 2 (Nielsen 2011: 422, n. 3.1.4.2): “Nunc autem differentia dividens actionem et passionem ab aliis entibus est secundum Philosophum, IV Metaphysicae, quod sunt entia, non quae fiant, sed factiones, quibus alia fiunt. Unde sunt viae vel exitus in esse, ut dicit."

53. Scriptum in I Sent. 27.1.2 (2009: 16, 11. 645-647): "[Actio] non est aliud quam intervallum sive via agentis in passum, seu attingentia secundum quam dicitur agens attingere effectum, et egredi ac fluere in ipsum ..."

54. Scriptum in I Sent. 27.1.2 (2009: 17, 11. 714-715): "[F]ormalis ratio actionis non est aliud quam quidam egressus huius in hoc, est enim attingentia qua formaliter agens dicitur effectum attingere et causare..." 
an agent to its effect in the patient during a causal interaction. 55 In contrast with Aquinas's view, action is not the motion which the agent produces in the patient. Rather, for Auriol action is a really distinct causal intermediary which intervenes between the agent and the motion it brings about.

Though Auriol maintains that actions are really distinct from the effects which they bring about, he nevertheless maintains that an action cannot exist on its own apart from some effect (i.e., a form) produced through it. ${ }^{6}$ In his view, action is essentially causal attaining or causality. ${ }^{57} \mathrm{He}$ thinks that there cannot be causality without there also being some something which is brought about through it..$^{8}$ Auriol claims that although there is never a time when action exists apart from the effect caused through it, action is nevertheless causally prior its effect.59 In Auriol's view, the effect depends on the action by way of origin and the action depends on the effect as the subject in which it inheres. ${ }^{60}$ This latter aspect of Auriol's position was subject to much criticism. If action or causality depends on its effect as the subject in which it exists, it seems that the existence of the action's effect is a condition of the action's own existence. But it is incoherent to suppose that the effect of an entity $e$ is itself part of the condition which must be met for $e^{\prime}$ s existence. Ockham, for example, was moved by such concerns to conclude that productive causality (i.e., action) could not be an entity over and above the effect produced. According to him, if it is supposed that productive

55. Quodl. q. 2 (Nielsen 2011: 415, n. 2.4.1): “[A]ctio est medium inter agens et formam actam, non quidem medium situale vel distantiae, sed causale, est enim prius origine et causaliter forma producta et posterius agente. Et Commentator, I Caeli et Mundi, III etiam Physicorum, comment 21, dicit, quod haec est "dispositio" actionis, quod est "existens inter duo," scilicet inter agens et formam actam. Unde patet, quod Philosophus vocat eam 'viam,' Commentator 'intermediam.' Et si vocetur 'intervallum,' idem est sicut 'via."' In IV Sent. q. 2, a. 2, p. 126 a-b (Nielsen 2011: 390, note 44): “. . est actus B in ordine ad A, ligans B cum ipso A."

56. Scriptum in I Sent. 27.1.2 (2009: 21, 11. 855-859): "Cum enim actio non possit per se subsistere ... per necessitatem, omnis actio exigit aliquid, cui coexistat, quod quidem sit [ . . ] subiectum et fundamentum ipsius, sicut in creaturis motus vel forma simplex product sunt fundamentum actionis." See also Quodl. 2, 2.4 (Nielsen 2011: 414, 11. 5-9).

57. Scriptum in I Sent. 27.1.2 (2009: 19, 11. 787-788): "[C]ausalis attingentia directe spectat et constituit praedicamentum actionis ..."

58. As we have seen, Aquinas refers to motion as the immediate effect of an agent in its patient. Auriol, by contrast, identifies the immediate effect of an agent in its patient as a "form." $\mathrm{He}$ does this both to make room for actions which are not motions and because he thinks motion is reducible to the form which is its end-point. For discussion of this point, see Löwe (2017: 247-249).

59. For a text in which Auriol distinguishes between temporal priority and causal priority, see Scriptum in I Sent. 27.1.2 (2009: 20, 11. 827-831). In this text he also claims that action is causally - not temporally - prior to that which is produced through it.

6o. There is some disagreement between contemporary scholars about Auriol's views on whether action exists in a subject. Nielsen claims that Auriol's actions have no bearer and hang in mid-air (2011: 394). By contrast Amerini argues that actions inhere in the patient as subject (2014: 521). I am following the position of Löwe whom I believe successfully resolves the dispute between these readings (2017: 261-265). 
causality is not the same entity as its effect, there would be no coherent way to understand the order of ontological dependence between causal activity and its effect. $^{61}$

Auriol's position on the ontological status of action can be summarized as follows: In addition to the agent and the patient, and their respective causal powers, paradigm instances of efficient causation include both a motion and a really distinct and separable action. Though action cannot exist apart from some effect which it brings about, action is an entity over and above the agent and the effect. Action is a dynamic, fleeting, essentially causative entity which is the causal link between the agent and its effect. As we saw in Auriol's argument regarding projectile motion, he maintained that the effect produced by the agent could persist even after the agent's action ceased. Actions exist only so long as the effect is actively being brought about by the agent. In Auriol's view, substances only causally impact the world in virtue of an intervening transitory causal entity.

\section{The Historical Significance of Auriol's Views on Action and Motion}

As is well known, there are many important differences between how medieval Aristotelian philosophers and their early modern successors conceived of the physical world. Scholars of late medieval and early modern philosophy are coming to appreciate that many of the conceptual shifts away from the Aristotelian worldview began already in the late medieval period. In this final section, I will highlight how Auriol's views on action reveal that some characteristically modern views about causation and motion were already present in medieval philosophy.

It is a standard scholarly view that prior to the eighteenth century philosophers and scientists thought that the causes of events in nature were substances or stable objects. There is certainly evidence in the writings of prominent seventeenth-century figures to support this assessment. As already noted in the introduction, Descartes explicitly endorsed the Aristotelian view, which we examined in Aquinas, that an agent's action is the same as the motion which it causes in its patient. For instance, he writes in a letter to Regius, "in corporeal things, every action and passion consists simply in local motion, and one calls this motion an action when it is considered in the mover and a passion when

61. Ockham argues that one cannot be prior to the other and they cannot be equal in priority, so he concludes that an agent's productive causality is not a res distinct from what the agent produces. Cf. Quodlibet VI, q. 12 ["Utrum relatio causalitas effectivae sit alia res a rebus absolutis"], (1967-1986: IX 629-633). For a discussion of Ockham's views on action and a discussion of his response to Auriol's 'metaphysical arguments' above, see Brower-Toland (2017: §3). 
it is considered in the thing moved." ${ }^{\prime 2}$ It follows from the thesis that action is motion, that agent substances cause motion immediately. There are no causal intermediaries. Mechanical philosophers like Descartes adopted a sparse ontology of the physical world including only physical bodies, characterized solely by their three-dimensional extension, and motion. Other figures in his 'mechanical' tradition explicitly deny that physical substances cause motion through fleeting, intermediary causative entities. For instance, Pierre Gassendi's disciple Walter Charleton writes that in an efficient causal interaction "nothing is impressed [by the agent], but the very motion to be continued through a certain space" (1654: 465). Physical substances, which are stable, persistent entities, are the immediate and only causes of motion. There are no dynamic, transitory causative entities which intervene between a physical substance and the motion which it causes.

In contrast with this view, Isaac Newton is regarded as one of the first figures to posit, in addition to substances and motions, fleeting, dynamic causative entities which exist when an efficient causal interaction is taking place between physical bodies. In Newton's view, one body causes motion in another, not immediately, but rather in virtue of a mediating impressed force. Newton writes in his Principia definition 4, "An impressed force is the action exerted upon a body to change its state either of resting or of moving uniformly straight forward." 63 Impressed forces are a different sort of reality from substances. They are fleeting in their existence in so far as they do not persist after a causal interaction has taken place. Furthermore, unlike substances, they are essentially causative entities. Their sole function is to change a body's state from rest to motion or vice versa and they only exist while they are fulfilling this function. Scholars have regarded Newton, as well as other eighteenth-century figures, as breaking away from earlier presuppositions about what sorts of entities function as causes. ${ }^{64} \mathrm{In}$ his view, the immediate cause of a motion is not a substance or stable object, but rather a transitory, fleeting force. ${ }^{65}$

In an attempt to uncover an earlier legacy for the modern concept of a force, others have noted that medieval thinkers similarly posited transitory, essentially

62. AT III: 454, CSMK III: 199. In his laws and in other passages Descartes makes reference to force (vis). See for instance AT VIII-1: 65 . Yet, he conceives of force as a property of a body associated with its motion rather than a transitory entity which exists just as long as a causal interaction is occurring.

63. Isaac Newton, The Principia: Mathematical Principles of Natural Philosophy (Newton 1999: 404).

64. See Footnote 5.

65. Newton maintains that substances are the agents to which actions are attributed. For discussion of how Newton's conception of dynamical causes relates to his concept of substantial causes, see Janiak (2013). It should also be noted that Newton scholars have disagreed about whether Newton thought that forces actually existed. For the negative position, see Cohen (1992: 347 ) and for the positive see Westfall (1971: 377). For an analysis of their disagreement, see Janiak (2008: ch. 3). 
causative entities to explain the motion of celestial bodies and how projectiles were kept in motion after they were launched. ${ }^{66}$ As we saw above, thinkers such as Aquinas conceived of the projecting substance as impressing a force on the projectile (or the air surrounding it) which causes the projectile to continue to move. While these medieval forces were ontologically similar to Newton's forces in so far as they were transitive and essentially causative entities, they nevertheless had a very different functional role. After the projecting substance set the projectile in motion, these forces cause the persistence of uniform motion. By contrast, Newton's impressed forces cause the very change in a body's state of motion or rest - not the continuance of uniform motion.

The striking feature of Auriol's actions is that they are both ontologically and functionally quite similar to Newton's impressed forces. From an ontological perspective, Auriol's actions are transitory, causative entities like Newton's forces. More significantly, they also function like these forces, in so far as they cause changes in motion. According to Auriol's views on projectile motion, the agent's action ceases once it changes the projectile from a state of rest to motion. The action causes only the change in state, not the projectile's continued motion. As we saw in the arguments above, Auriol thinks that whenever a physical agent moves a physical patient, an action exists between the agent and the patient and it causes the motion which comes to be in the patient. Like Newton's impressed forces, Auriol's actions are causal intermediaries which bring about changes in a body's state with respect to motion.

It is interesting to note that Newton identifies his impressed forces with actions. He writes of impressed forces in his Principia, "This force consists solely in the action and does not remain in the body after the action has ceased." 67 Unlike Descartes, Newton does not identify an agent substance's action with the motion it causes. Rather, he identifies the agent's action with the force in virtue of which it causes motion. Like Auriol, he distinguishes the action through which an agent causes motion from the motion itself. Newton's identification of impressed forces with actions raises the question of whether earlier scholastic debates about the ontological status of action influenced later thinking about the concept of force. In reflecting on the nature of action, medieval figures like Auriol had already in the fourteenth century articulated a metaphysics of efficient causation which employed a dynamic entity, over and above motion, to causally account for changes from rest to motion. This conception of action as ontologically distinct from and causally prior to motion may have been a model for later conceptions of forces. ${ }^{6}$

66. See, for instance, Jammer (1957: ch. 4).

67. Newton, The Principia: Mathematical Principles of Natural Philosophy (Newton 1999: 404).

68. It is quite possible that Auriol's writings had actual influence on early modern figures as his importance was widely recognized in this period. His major works were edited 1596 and 1605; 
The second historically noteworthy feature of Auriol's account of action is the implications it has for his concept of motion. As we saw earlier, Aquinas identified motion with the manifestation of an agent's active power. In his view, motion is itself the very reality of the causal interaction between agent and patient. Motion is conceived of as a reality which is at once arising from one substance and being received in another. When motion is considered as both the manifestation of active power and the very reality which constitutes the causal interaction between agent and patient, motion which occurs without an active cause seems to be a metaphysical impossibility. Motion, action and passion are one and the same actuality. By introducing a further entity which is really distinct from motion to constitute the agent's action, Auriol in effect divorces motion from causal activity. On his view, motion is not the very entity which is the manifestation of active power. The agent's causing of motion and the patient's reception of motion are really distinct realities from the motion itself. Furthermore, motion is not the very reality of the causal interaction between agent and patient. Rather, it is a non-causal effect which results from the agent's prior exercise of its causality.

By arguing that the causal activity which changes an object from rest to motion must be something other than the object's motion itself, Auriol makes a metaphysical move which is required for conceiving of motion as a state on par with rest rather than an entity constantly arising from an agent cause. ${ }^{69}$ As we have seen, Auriol himself thinks that projectile motion persists without the action of an efficient cause. These striking features of Auriol's conception of motion go against common scholarly accounts of medieval views and their relation to latter, modern ones. The standard account maintains that medieval thinkers held motion was a change undergone by a body and continually produced through an agent cause. According to this account, it was not until the early modern period that this conception of motion was overthrown.

and later in the century, Bartholomew Mastrius referred to Auriol as 'a source of inspiration for the moderns.' See Schmutz (2012: 247). Even those who did not read Auriol's works directly may have encountered his views on action, passion and motion in John of Capreolus, a prominent Thomist whose works were also edited in the sixteenth century. Capreolus copied verbatim Auriol's arguments against Aquinas's standard Aristotelian view on action, passion and motion. See John Capreolus, In Libros Sententiarum applissimae quaestiones. . . , Bk II. d.I, q. 32 [“Utrum creatio sit aliud”] (1589: II 21-22). The text which Capreolus copies is Auriol's I Sent. d. 27.

69. Those who have attempted to uncover medieval background or precursors to the modern concept of inertial motion have focused for the most part on medieval theories which posited impressed forces that kept celestial bodies and projectiles in motion. For a very influential study which claims that fourteenth-century impetus theory was a precursor to Galileo and Newton's theories of inertial motion, see Duhem (1913). According to Anneliese Maier (1940), the attempt to characterize "impetus theory" as precursor to inertial motion is misguided since, while the theory suggests a new account of what the cause of projectile or celestial motion is, it nevertheless rests on the assumption that all motion must be the constant action of a cause. For a useful summary of differing scholarly perspectives on the relationship of Galileo to his predecessors see Weisheipl (1985: ch. 3). 
Descartes's most important contribution to physics is commonly thought to be his reconceptualization of motion as a non-causal state. Alexander Koyré wrote, "All the disagreement between ancient and modern physics may be reduced to this: whereas for Aristotle, motion is necessarily an action, or more precisely an actualization ... it became for Galileo and Descartes a state."70 As we have already seen, Descartes continued to accept the Aristotelian view that an agent's action is the motion which it causes in its patient. In light of Descartes' acceptance of the Aristotelian action-passion sameness thesis, Paul Hoffman has argued that Descartes' reconceptualization of motion was not quite as radical as is usually believed. According Hoffman, while Descartes ceases to regard locomotion as the actualization of a potential, he nevertheless continues to regard it as a passion which a body suffers or undergoes through a cause. This is to say that though motion is a state for Descartes, rather than a change, it is nevertheless a state which is constantly sustained by a productive agent cause. On Hoffman's interpretation, Descartes regards even inertial motion as an action caused by a body on itself. On this narrative, Newton's achievement over Descartes was his ceasing to regard motion as a passion which demands a corresponding action..$^{11}$ My goal here is not to make a pronouncement on the proper interpretation of Descartes' views or the differences between his views and Newton's. Regardless of whether one credits Descartes or Newton with the ontological separation of motion from causality, Auriol's texts show that already in the fourteenth century there were thinkers who had ceased to regard locomotion as a causal process ontologically identical with action and passion. As we have seen, on Auriol's view motion is really distinct and ontologically separable from an action. This move in ontology is a pre-requisite for conceiving of motion as a state on par with rest which can persist without the constant activity of an agent cause. The presence of views like Auriol's in the medieval period should challenge us to re-think what the key differences are between medieval and modern conceptions of motion. The full story about the historical understanding of motion will likely turn out to be a complicated one with several parallel plots unfolding at once. Just as there continued to be fervent defenders of Aristotelianism in the early modern period, so too were there already harsh critics of Aristotelian theses about motion in the middle ages.

70. Koyré (1961: 30, note 1). The translation is quoted from Weisheipl (1985: 58).

71. Hoffman writes the following in his essay "Passion and Motion in the New Mechanics" (Hoffman 2009: 141): "The significance for Descartes of viewing motion as a state concerns final causation: states do not necessarily have an endpoint or final cause. But once motion is seen as a state and not as a change, then the way is paved for Newton to cease regarding motion as a passion and thus to cease viewing uniform rectilinear motion as requiring an active cause. This in turn paved the way for us to dispense with the notion of an inactive cause of motion and to reach our modern conception of inertia in which no cause is required for a body to continue to move uniformly in a straight line." 


\section{Acknowledgements}

Earlier versions of this paper were presented at the University of Toronto conference on Activity, Spontaneity and Agency in Later Medieval and Early Modern Philosophy, the Symposium on Post-Aristotelian Natural Philosophy at the 2016 meeting of the International Society for the History of Philosophy of Science (HOPOS) and the 2019 Midwest Colloquium for Medieval Philosophy hosted by the University of Notre Dame. I am grateful to the audiences at these events for helpful discussion and especially to Han Thomas Adriaenssen for the comments he delivered at the UT conference mentioned above. I would also like to thank the Ergo editor and referees for their careful and constructive comments.

\section{Abbreviations}

$A T=$ Descartes, René (1964-1976). Oeuvres de Descartes (Vols. 1-11). Charles Adam and Paul Tannery (Eds.). Vrin. Cited by volume and page number. CSMK = Descartes, René (1985-1991). The Philosophical Writings of Descartes (Vols. 1-3). John Cottingham, Robert Stoothoff, Dugald Murdoch, and Anthony Kenny (Eds. and Trans.). Cambridge University Press. Cited by volume and page number.

De ver. $=$ Thomas Aquinas (1970-76). Quaestiones disputatae de veritate. In Opera omnia. Editio Leonina (Vol. 22/1-3). Editori di San Tommaso. Cited by question and article number.

De pot. $=$ Thomas Aquinas (1965). Quaestiones disputatae de potentia. Paulo M. Pession (Ed.). Marietti. Cited by question and article number.

In Meta. $=$ Thomas Aquinas (1964). In duodecim libros Metaphysicorum Aristotelis expositio. M.-R. Cathala and Raymundi M. Spiazzi (Eds.), Marietti. Cited by book, lectio, and paragraph number.

In Phys. = Thomas Aquinas (1884). In VIII libros Physicorum. In Opera omnia. Editio Leonina (Vol. 2). Editori di San Tommaso. Cited by book, lectio, and paragraph number.

ScG $=$ Thomas Aquinas (1961). Summa contra Gentiles. Ceslaus Pera, Petro Marc and Petro Caramello (Eds.), Marietti. Cited by book, chapter, and paragraph number.

$S T=$ Thomas Aquinas (1886-1906). Summa Theologiae. In Opera omnia. Editio Leonina (Vol. 4-12). Editori di San Tommaso. Cited by part number, question number, and article number. 


\section{References}

Alvarez, Maria and John Hyman (1998). Agents and Their Actions. Philosophy, 73(2), 219245. https://doi.org/10.1017/s0031819198000199

Amerini, Fabrizio (2014). Peter Auriol on Categories. Documenti e studi sulla tradizione filosofica medievale, 25, 493-535.

Aristotle (1984). Physics. In Jonathan Barnes (Ed.), The Complete Works of Aristotle (Vol. 1). Princeton University Press.

Aristotle (1988). Physics. William D. Ross (Ed.). Clarendon Press.

Bach, Kent (1980). Actions Are Not Events. Mind, 89(353), 114-120. https://doi.org/10.1093/ mind/LXXXIX.353.114

Brower, Jeffrey (2014). Aquinas's Ontology of the Material World. Oxford University Press. https://doi.org/10.1093/acprof:oso/9780198714293.001.0001

Brower-Toland, Susan (2017). Causation and Mental Content: Against the Externalist Reading of Ockham. In Jenny Pelletier and Magali Roques (Eds.), The Language of Thought in Late Medieval Philosophy: Essays in Honour of Claude Panaccio (59-80). Springer. https://doi.org/10.1007/978-3-319-66634-1

Capreolus, John (1589). In Libros Sententiarum applissimae quaestiones . . . Venice.

Charleton, Walter (1654). Physiologia Epicuro-Gassendo-Charlotoniana. Tho. Newcomb, for T. Heath.

Cohen, Bernard (1992). The Review of the First Edition of Newton's Principia in the Acta Eruditorum, with Notes on the Other Reviews. In P. M. Harman and Alan Shapiro (Eds.), The Investigation of Difficult Things: Essays on Newton and the History of the Exact Sciences in Honour of D. T. Whiteside ( $\mathrm{p}-\mathrm{p})$. Cambridge University Press. https://doi. org $/ 10.1163 / 221058784 \times 00823$

Coope, Ursula (2007). Aristotle on Action. Aristotelian Society Supplementary Volume, 81(1), 109-138. Oxford University Press. https://doi.org/10.1111/j.1467-8349.2007.00153.x

Descartes, René (1964-1976). Oeuvres de Descartes (11 Vols.). Charles Adam and Paul Tannery (Eds.). Vrin. https://doi.org/10.5962/bhl.title.39750

Descartes, René (1985-1991). The Philosophical Writings of Descartes (3 Vols.). John Cottingham, Robert Stoothoff, Dugald Murdoch, and Anthony Kenny (Eds. and Trans.). Cambridge University Press. https://doi.org/10.1017/cbo9781107340824

Duhem, Pierre (1913). Les précurseurs parisiens de Galilée. A. Hermann.

Ford, Anton (2014). Action and Passion. Philosophical Topics, 42(1), 13-42. https://doi. org/10.5840/philtopics20144212

Friedman, Russell L. (1997). In principio erat Verbum: The Incorporation of Philosophical Psychology into Trinitarian Theology, 1250-1325 (Unpublished doctoral dissertation). University of Iowa.

Frost, Gloria (2018). Aquinas's Ontology of Transeunt Causal Activity. Vivarium, 56(1-2), 47-82. https://doi.org/10.1163/15685349-12341351

Gassendi, Pierre (1972). Letter to Diodati. In Craig B. Brush (Ed. and Trans.), Selected Works of Pierre Gassendi ( $\mathrm{p}-\mathrm{p})$. Johnson Reprint Corporation.

Gill, Mary Louise (1980). Aristotle's Theory of Causal Action in Physics III 3. Phronesis, 25(2), 129-147. https://doi.org/10.1163/156852880X00089

Hoffman, Paul (2009). Essays on Descartes. Oxford University Press.

Jammer, Max (1957). Concepts of Force: A Study in the Foundations of Dynamics. Harvard University Press. 
Janiak, Andrew (2013). Three Concepts of Causation in Newton. Studies in History and Philosophy of Science, 44(3), 396-407. https://doi.org/10.1016/j.shpsa.2012.10.009

Janiak, Andrew (2008). Newton as Philosopher. Cambridge University Press.

Janiak, Andrew (2016). Newton's Philosophy. In Edward N. Zalta (Ed.), The Stanford Encyclopedia of Philosophy (Winter 2016 Edition). Retrieved from https://plato.stanford. edu/archives/win2016/entries/newton-philosophy/

Keele, Rondo (2007). Can God Make a Picasso? William Ockham and Walter Chatton on Divine Power and Real Relations. Journal of the History of Philosophy, 45(3), 395-411. https://doi.org/10.1353/hph.2007.0063

Koyré, Alexander (1961). Études d'histoire de la pensée philosophique. Arman Colin.

Lowe, E. J. (2002). A Survey of Metaphysics. Oxford University Press.

Löwe, Can (2017). Peter Auriol on the Metaphysics of Efficient Causation. Vivarium, 55(4), 239-272. https://doi.org/10.1163/15685349-12341344

Maier, Anneliese (1940). Die Impetustheorie der Scholastik. Verlag Anton Schroll \& Co.

Marmodoro, Anna (2007). The Union of Cause and Effect in Aristotle: Physics III 3. Oxford Studies in Ancient Philosophy, 32, 205-232.

Newton, Isaac (1999). The Principia: Mathematical Principles of Natural Philosophy (Bernard Cohen and Anne Whitman, with the assistance of Julia Budenz, Ed. and Trans.). University of California Press. https://doi.org/10.1086/386435

Nielsen, Lauge (2011). Peter Auriol on the Categories of Action and Passion: The Second Question of His Quodlibet. In Andreas Speer, Russel Friedman, Kent Emery (Eds.), Philosophy and Theology in the Long Middle Ages: A Tribute to Stephen F. Brown. Studien und Texte zur Geistesgeschichte des Mittelalters (Vol. 105, 375-436). Brill Academic Publishers. https://doi.org/10.1515/hzhz.2013.0437

Pasnau, Robert (2011). Metaphysical Themes: 1274-1671. Oxford University Press. https:// doi.org/10.1093/acprof:oso/9780199567911.001.0001

Paul, Laurie A. and Ned Hall (2013). Causation: A User's Guide. Oxford University Press. https://doi.org/10.1093/acprof:oso/9780199673445.001.0001

Peter Auriol (1605a). Commentaria in secundum librum Sententiarum. Rome.

Peter Auriol (1605b). Commentaria in quartum librum Sententiarum. Rome.

Peter Auriol (2009). Scriptum in I Sent., d. 27 [PDF document]. Russell Friedman (Ed.). Retrieved from The Electronic Scriptum on the Peter Auriol Homepage: http:// www.peterauriol.net/auriol-pdf/SCR-27-1.pdf https://doi.org/10.1007/springerreference_187800

Peter Olivi (1922). Quaestiones in secundum librum Sententiarum. Bernhard Jansen (Ed.). Typographia Collegii S. Bonaventurae.

Schickel, Joel A. (2011). Descartes on the Identity of Passion and Action. British Journal for the History of Philosophy, 19(6), 1067-1084. https://doi.org/10.1080/09608788.2011. 624703

Schmutz, Jacob (2012). Medieval Philosophy after the Middle Ages. In John Marenbon (Ed.), Oxford Handbook of Medieval Philosophy (245-270). Oxford University Press. https://doi.org/10.1093/oxfordhb/9780195379488.013.0011

Soncinas, Paul (1498). Quaestiones Metaphysicae. Venice.

Suárez, Francisco (1866). Disputationes Metaphysicae. In Charles Berton (Ed.), Opera Omnia (Vols. 25-26). Vivès.

Thomas Aquinas (1884). In VIII libros Physicorum. In Opera omnia. Editio Leonina (Vol. 2). Editori di San Tommaso. 
Thomas Aquinas (1886-1906). Summa Theologiae. In Opera omnia. Editio Leonina (Vol. 412). Editori di San Tommaso.

Thomas Aquinas (1961). Summa contra Gentiles. Ceslaus Pera, Petro Marc, and Petro Caramello (Eds.). Marietti.

Thomas Aquinas (1964). In duodecim libros Metaphysicorum Aristotelis expositio. M.-R. Cathala and Raymundi M. Spiazzi (Eds.). Marietti. https://doi.org/10.5840/schoolman195128410

Thomas Aquinas (1965). Quaestiones disputatae de potentia. Paulo M. Pession (Ed.). Marietti.

Thomas Aquinas (1970-76). Quaestiones disputatae de veritate. In Opera omnia. Editio Leonina (Vol. 22/1-3). Editori di San Tommaso.

Tomarchio, John (1998). Four Indices for the Thomistic Principle Quod recipitur in aliquo est in eo per modum recipientis. Mediaeval Studies, 60(1), 315-367. https://doi. org/10.1484/J.MS.2.306684

Tomarchio, John (1999). Thomistic Axiomatics in an Age of Computers. History of Philosophy Quarterly, 16(3), 249-275.

Tomarchio, John (2001). Aquinas's Division of Being According to Modes of Existing. Review of Metaphysics, 54(3), 585-613.

Tuttle, Jake (2016). Suárez's Non-Reductive Theory of Efficient Causation. Oxford Studies in Medieval Philosophy, 4, 125-158. https://doi.org/10.1093/acprof:o so/9780198786368.001.0001

Weisheipl, James OP (1985). Galileo and the Principle of Inertia. In William Carroll (Ed.), Nature and Motion in the Middle Ages (49-73). Catholic University of America Press.

Westfall, Richard (1971). Force in Newton's Physics. American Elsevier.

William of Ockham (1967-1986). Opera Theologica. Franciscan Institute of St. Bonaventure University. 